\title{
Management of Lotus corniculatus under dairy cow grazing
}

\author{
E.M.K. MINNEÉ, S.J. BLUETT, S.L. WOODWARD and P.G. LABOYRIE \\ Dexcel, Private Bag 3221, Hamilton. \\ elena.minnee@dexcel.co.nz
}

\begin{abstract}
The effect of lax or hard dairy cow grazing (residual stubble height of 10 and $5 \mathrm{~cm}$ ) and grazing frequency (grazing when sward height reached 35 or $20 \mathrm{~cm}$ ) on persistence, productivity and forage quality of pure pastures of Lotus corniculatus was evaluated over two growing seasons. Herbage accumulation was not affected by grazing frequency or severity. In year one, hard, infrequent defoliation significantly increased forage fibre content and reduced concentration of crude protein, soluble sugars, organic matter digestibility and metabolisable energy. Under frequent grazing, condensed tannin concentration was reduced by $15 \%(\mathrm{P}<0.001)$. Differences in forage quality are likely to be associated with increased amounts of fibrous stem material in infrequently grazed pastures $(\mathrm{P}<0.001)$. Plant populations declined in all treatments after 2 years.
\end{abstract}

Keywords: Lotus corniculatus, dairy cows, grazing management

\section{Introduction}

The New Zealand dairy industry has set a goal to increase dairy farmer profit and create wealth for the New Zealand economy by achieving a $50 \%$ gain in productivity by 2015. Experiments at Dexcel showed that feeding Lotus corniculatus (lotus) to dairy cows increased milk production per cow (Harris et al. 1998; Woodward et al. 1999). Lotus is a high quality, non-bloating perennial legume that is tolerant of drought and low soil fertility. The main growth period is from spring until late autumn, with almost no growth over winter. Yields from pure stands of lotus can reach 10 to $15 \mathrm{t} \mathrm{DM} / \mathrm{ha} / \mathrm{yr}$ under good growing conditions and careful management (Waghorn et al. 1998). However, factors limiting the use of lotus in New Zealand dairy farm systems include poor productivity and persistence. Yields of $7.5 \mathrm{t} \mathrm{DM} /$ ha/yr were reported by Bologna et al. (1996) while Scheaffer et al. (1992) reported that monocultures of lotus, initially more than $95 \%$ pure deteriorated to $20 \%$ ( $80 \%$ broadleaf weeds) by the fourth year of grazing by sheep. Much of the published literature on managing lotus is based on cutting experiments, overseas research and experiments involving sheep. Although lotus has shown promise as high quality forage for dairy cows that may help achieve industry goals, management guidelines for grazing must be developed specifically for New Zealand dairying systems.
The objective of this study was to evaluate the effects of severity and frequency of grazing by dairy cows on the productivity and persistence of lotus over two growing seasons.

\section{Materials and Methods \\ Experimental design}

Plots were arranged in a randomised complete block design with four treatments replicated three times, each plot measuring $20 \mathrm{~m}^{2}$. Treatments were: Frequent Hard grazing (FH); Frequent Lax grazing (FL); Infrequent Hard grazing (IH); Infrequent Lax grazing (IL). Treatment selection was based on research by Alison and Hoveland (1989a, b) and Pierre and Jackobs (1953). These treatments were arranged in a $2 \times 2$ factorial design with either lax or hard grazing (residual stubble height of 10 or $5 \mathrm{~cm}$, respectively) combined with infrequent or frequent grazings (sward height of 35 or $20 \mathrm{~cm}$, respectively).

\section{Experimental site and establishment}

The experiment was conducted from February 2002 to March 2004 at Dexcel's No. 5 Dairy near Hamilton, $\left(37^{\circ} 47^{\prime} \mathrm{S}, 175^{\circ} 19^{\prime} \mathrm{E}\right)$. The soil type at the site was Te Kowhai clay loam (Singleton 1991), classified (Hewitt 1998) as a Typic Orthic Gley. Rainfall and temperature data were recorded at the Ruakura Climatological Station c. $1 \mathrm{~km}$ north-west of the site.

Existing pastures were sprayed out in February 2002 with $4 \mathrm{~L} /$ ha Roundup ${ }^{\circledR}$, before ploughing. Fertiliser (4t/ ha lime, $550 \mathrm{~kg} / \mathrm{ha} 10 \%$ potash super, $50 \mathrm{~kg} / \mathrm{ha}$ magnesium $)$ and a pre-emergent herbicide spray $(2.5 \mathrm{~L} /$ ha Treflan) were applied before power harrowing and rolling to form a fine seedbed. Bare L. corniculatus (cv. Grasslands Goldie) seed was inoculated with Rhizobium loti immediately before sowing which was carried out at $6 \mathrm{~kg} / \mathrm{ha}$ by roller drill. In July 2002 after seedling emergence, a post-emergent herbicide (4 L/ha 2-4-DB and $0.5 \mathrm{~L} /$ ha Combine) was applied.

\section{Measurements}

Experimental data were collected throughout the growing season (September to April) of each year. Plots were 'rested' during winter (May to August) to avoid depleting plant carbohydrate reserves (Ayala et al. 2000).

Average mean sward height of each plot was monitored weekly, using an automated sward stick, taking 20 
random measurements per plot. Dairy cows grazed treatment plots when the average sward height was at target pre-grazing height. Sward height was monitored throughout grazing and cows were removed when target residual height was achieved.

Herbage accumulation was determined by cutting 10 x $0.2 \mathrm{~m}^{2}$ quadrats per plot to ground level before and after grazing (residual) using an electric shearing handpiece. Herbage samples were washed, oven-dried at $95^{\circ} \mathrm{C}$ for 48 hours, and weighed. Herbage accumulation was defined as: $\Sigma$ (present pre-grazing herbage mass previous residual herbage mass).

Prior to grazing, 10 herbage samples were hand-clipped to residual grazing height $(5$ or $10 \mathrm{~cm})$ from random locations within each plot before bulking. A $150 \mathrm{~g}$ subsample of herbage was frozen, freeze dried and ground to pass a $1 \mathrm{~mm}$ diameter sieve, and analysed by NIRS (near infrared reflectance spectroscopy) for indicators of feed quality (Corson et al. 1999) and condensed tannin concentration. A second sub-sample $(\sim 100 \mathrm{~g})$ was dissected into lotus leaf, stem, flowers, seedpods, weeds and dead material. Dissected samples were dried at $95^{\circ} \mathrm{C}$ for 48 hours before weighing to estimate botanical composition on a dry matter basis.

Plant density was measured bi-monthly during the experimental periods by removing $10 \times 0.12 \mathrm{~m}^{2}(15 \mathrm{~cm}$

Table 1 Herbage accumulation (t DM/ha) of Lotus corniculatus comparing levels of frequency (frequent, infrequent) and levels of severity (lax, hard) of grazing by dairy cows.

\begin{tabular}{lcc}
\hline Treatment & Year 1 & Year 2 \\
\hline Frequent Hard (FH) & 10.4 & 6.0 \\
Frequent Lax (FL) & 11.8 & 5.7 \\
Infrequent Hard (IH) & 12.2 & 6.0 \\
Infrequent Lax (IL) & 13.0 & 5.4 \\
SED & 1.8 & 1.0 \\
P (Grazing frequency) & 0.272 & 0.535 \\
P (Grazing severity) & 0.416 & 0.254 \\
P (interaction) & 0.821 & 0.514 \\
\hline
\end{tabular}

deep) turves from each plot. Soil was washed from each turf, and the number of plants per turf recorded.

Data were analysed as a factorial design. Analysis of variance was used to test for treatment differences and interactions using Genstat 8.1.

\section{Results}

Rainfall during each growing season was generally similar to the 10 -year average $(1160 \mathrm{~mm})$. However in February 2004, rainfall was $420 \%$ greater than the 10 year average $(69.5 \mathrm{~mm})$. Soil temperatures $(10 \mathrm{~cm}$ below surface) were also similar to the 10 -year average $\left(13.8^{\circ} \mathrm{C}\right)$ (AgResearch, Ruakura).

There were no significant differences in herbage accumulation between treatments in either year, although there was a substantial drop in yield across all treatments from year one to year two (between 42 and 59\%) (Table 1). Average grazing interval for each treatment across both seasons was 37 days for FH, 30 days for FL, and 45 days for both IH and IL plots.

Nutritive characteristics as indicators of feed quality are summarised in Table 2. A significant interaction for grazing frequency $\mathrm{x}$ severity was detected in year one for concentration of soluble sugars $(\mathrm{SS})(\mathrm{P}<0.01)$, neutral detergent fibre $(\mathrm{NDF})(\mathrm{P}<0.01)$ and organic matter digestibility $(\mathrm{OMD})(\mathrm{P}<0.05)$. Under infrequent grazing concentrations of SS and OMD were reduced, while NDF increased compared to frequently grazed pastures. Under hard grazing, NDF concentration increased while OMD was reduced compared to lax grazed treatments. Crude protein (CP) and metabolisable energy (ME) concentration were higher on frequently grazed treatments and under lax grazing $(\mathrm{P}<0.001)$, while concentration of condensed tannins were greatest under infrequent $(\mathrm{P}<0.001)$ and lax grazing $(\mathrm{P}<0.05)$.

Botanical composition for year one is described in Figure 1. A significant $(\mathrm{P}<0.01)$ interaction for grazing frequency $\mathrm{x}$ severity was detected for the proportion of lotus stem material in the forage in season one. Proportion of stem material was higher under infrequent grazing

Table 2 Nutritive characteristics (g/100 g DM, unless otherwise stated), averaged over all harvests in Year 1 (2002/2003), of Lotus corniculatus comparing frequency (frequent, infrequent) and severity (lax, hard) of dairy cow grazing on forage quality.

\begin{tabular}{lcccccc}
\hline Treatment & NDF $^{1}$ & $\mathrm{CP}^{2}$ & $\mathrm{ME}^{3}$ & $\mathrm{OMD}^{4}$ & $\mathrm{SS}^{5}$ & $\mathrm{CT}^{6}$ \\
\hline Frequent Hard (FH) & 23.7 & 24.7 & 11.3 & 79.6 & 13.5 & 4.5 \\
Frequent Lax (FL) & 22.5 & 26.3 & 11.5 & 81.5 & 13.2 & 4.6 \\
Infrequent Hard (IH) & 28.0 & 21.6 & 10.6 & 74.2 & 11.2 & 5.1 \\
Infrequent Lax (IL) & 23.6 & 23.3 & 11.1 & 77.9 & 12.7 & 5.5 \\
SED & 0.61 & 0.25 & 0.08 & 0.47 & 0.28 & 0.09 \\
P (Grazing frequency) & 0.001 & $<0.001$ & $<0.001$ & $<0.001$ & $<0.001$ & $<0.001$ \\
P (Grazing severity) & 0.001 & $<0.001$ & $<0.001$ & $<0.001$ & $<0.018$ & 0.017 \\
P (interaction) & 0.009 & 0.970 & 0.061 & 0.040 & 0.004 & 0.101 \\
\hline
\end{tabular}

${ }^{1} \mathrm{NDF}$, neutral detergent fibre; ${ }^{2} \mathrm{CP}$, crude protein; ${ }^{3 \mathrm{ME}}$, metabolisable energy, $\mathrm{MJ} / \mathrm{kg} \mathrm{DM} ;{ }^{4} \mathrm{OMD}$, organic matter digestibility; ${ }^{5} \mathrm{SS}$, soluble sugars; ${ }^{6} \mathrm{CT}$, condensed tannins. 
Figure 1 Sward botanical composition (\%) comparing frequency (frequent, infrequent) and severity (lax, hard) of grazing by dairy cows over 2 years.



Figure 2 Changes in Lotus corniculatus plant density (plants $/ \mathrm{m}^{2}$ ) comparing frequency (frequent, infrequent) and severity (lax, hard) of grazing by dairy cows in (a) year one and (b) year two. Error bars represent SED.

a

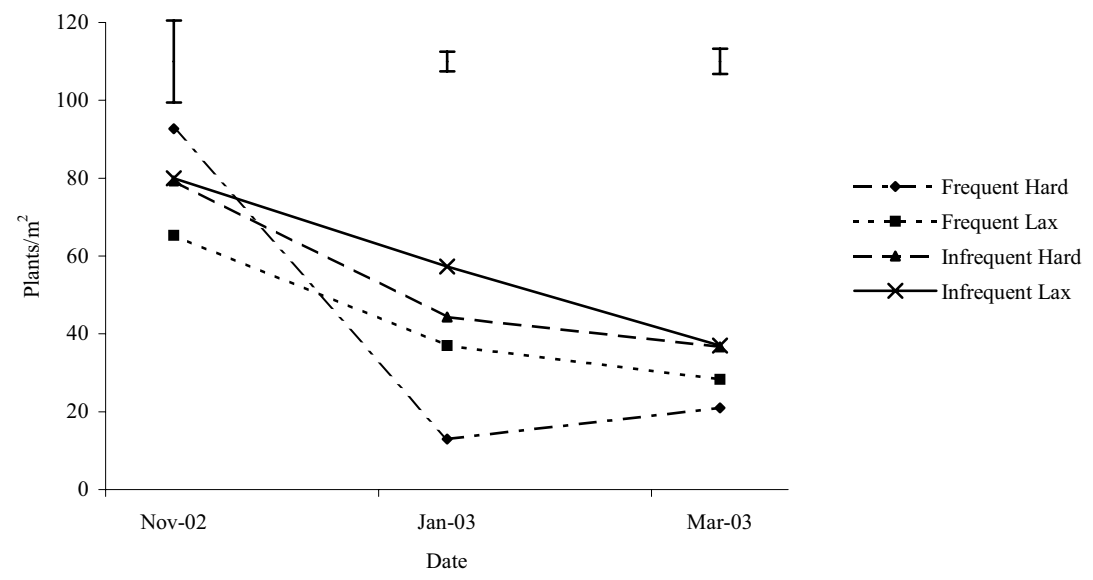

b

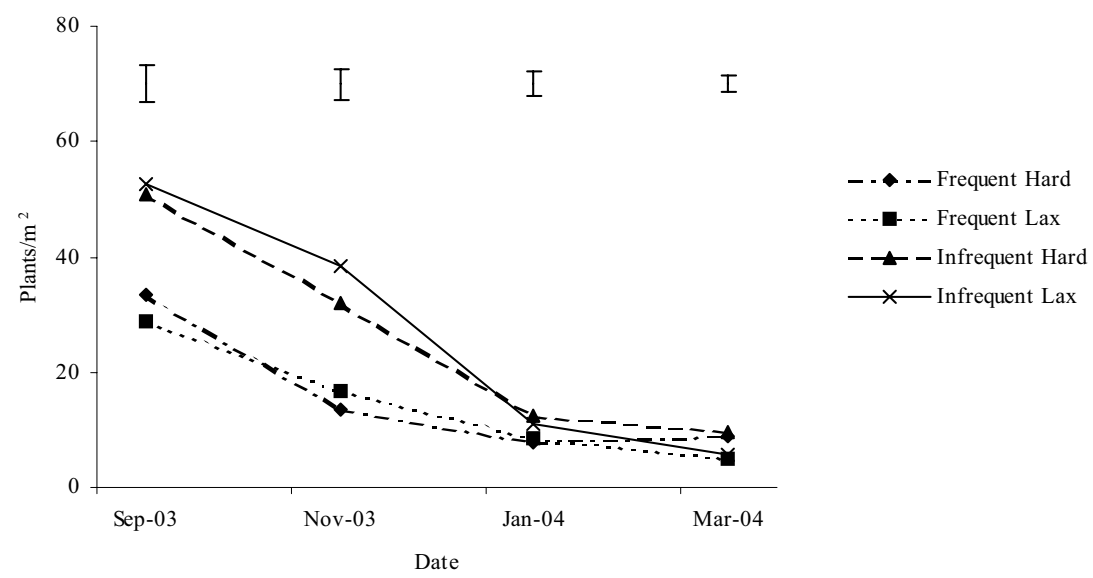


compared with frequent grazing, and was greater on hard grazed treatments compared to lax grazed treatments. In year one, proportion of flowers increased under infrequent grazing $(\mathrm{P}<0.001)$, but seedpod proportion was not affected by treatment. Weed content was greatest under frequent defoliation for both years $(\mathrm{P}<0.001$ and $\mathrm{P}<0.05)$. At the end of the year two, lotus accounted for only $43 \%$ of pasture dry matter.

Initially (November 2002), plant density of lotus was similar across all treatments, averaging 80 plants $/ \mathrm{m}^{2}$. Between November 2002 and January 2003 a substantial linear decline in plant density was observed (Fig. 2a). Plant density was significantly affected by grazing frequency with $\mathrm{IH}$ and IL $>$ than $\mathrm{FH}$ and $\mathrm{FL}(\mathrm{P}<0.001$ in January 2003, $\mathrm{P}<0.05$ in March 2003, $\mathrm{P}<0.001$ in September 2003 and $P<0.001$ in November 2003). Plant density was also affected by grazing severity in March 2004 when FH and IH had higher density than FL and IL $(\mathrm{P}<0.05)$. By March 2004, plant density was only 5 to $12 \%$ of the original plant population across all treatments (Fig. 2b).

\section{Discussion}

In this study, herbage production was not affected by grazing management. Yields observed in year one were moderate $(10.4$ to $13 \mathrm{t} \mathrm{DM} / \mathrm{ha})$ and similar to those reported by Bologna et al. (1996). The reduction in yield from year one to year two was associated with the decline in lotus stand density and ingression of weeds into the pasture. These results support the statement made by Pierre and Jackobs (1953) that lotus is essentially a "... short-lived perennial legume under grazing”. While, lotus did not show potential as a crop for high forage production, it may still be worthy of inclusion in dairy farming systems because of the nutritional benefits of lotus forage and animal production gains previously observed in other studies (Harris et al. 1998; Woodward et al. 1999).

In this study, both grazing severity and grazing frequency influenced forage quality. Infrequent and hard defoliation reduced forage quality. This was associated with an increase in fibrous stem material under infrequent defoliation. However, concentrations of the nutritional indicators were all within the ranges regarded as good quality forage for high producing ruminants (Kolver 2000). Concentrations of condensed tannins from forage from all grazing strategies were moderate and within the range likely to provide additional nutritional benefit to ruminants without depressing intake (Waghorn et al. 1998).

Competition between individual lotus plants may explain the substantial decline in plant numbers in the early part of this experiment. Most substantial plant losses were associated with frequent grazing. Regular treading damage to the plant crown, (the primary site for shoot regeneration after grazing) probably contributed to plant loss. In this study, after 2 years under dairy cow grazing, lotus stands were defunct.

Studies of grazing lotus by sheep under dryland farming showed that lotus stands persisted satisfactorily (i.e. maintaining at least $60 \%$ lotus in the sward) for 3 years (Widdup et al. 2004; Ramirez-Restrepo et al. 2006). Further investigation into whether lotus persists better under dairy cow grazing in dryland areas is required.

\section{Conclusion}

Grazing strategies imposed in this study did not influence herbage yield but did affect forage quality and stand persistence. Across all treatments, lotus dry matter production and plant density declined with time, but could be slowed using infrequent grazing, which also slowed ingression of weeds. Infrequent hard grazing resulted in a reduction in nutritive value, due to an increased proportion of stem material in the forage, and therefore infrequent lax grazing is the preferred grazing method.

\section{ACKNOWLEDGEMENTS}

Project funded by Dairy Insight. The authors wish to thank Dexcel technicians and farm staff from No. 5 dairy who helped with experimental measurements.

\section{REFERENCES}

Alison, M.W., Jr.; Hoveland, C.S. 1989a. Birdsfoot trefoil management. I. Root growth and carbohydrate storage. Agronomy Journal 81: 739-745.

Alison, M.W., Jr.; Hoveland, C.S. 1989b. Birdsfoot trefoil management. II. Yield, quality and stand evaluation. Agronomy Journal 81: 745-749.

Ayala, W.; Hodgson, J; Kemp, P. 2000. Changes in the morphology, production and population of Lotus corniculatus L. cv. Grasslands Goldie in response to seasonal defoliation regimes. Agronomy New Zealand 30: 93-100.

Bologna, J.J.; Rowarth, J.S.; Fraser, T.J.; Hill, G.D. 1996. Management of birdsfoot trefoil (Lotus corniculatus L.) pastures for productivity and persistence. Agronomy New Zealand 26: 17-21.

Corson, D.C.; Waghorn, G.C.; Ulyatt, M.J.; Lee, J. 1999. NIRS: Forage analysis and livestock feeding. Proceedings of the New Zealand Grassland Association 61: 127-132.

Harris, S.L.; Clark, D.A.; Laboyrie, P.G. 1998b. Birdsfoot trefoil - an alternative legume for New Zealand dairy pastures. Proceedings of the New Zealand Grassland Association 60: 99-103.

Hewitt, A.E. 1998. New Zealand soil classification. 2nd ed. Landcare Research Science Series 1. 
Kolver, E.S. 2000. Nutritional guidelines for the high producing dairy cow. pp 78-87. In: Proceedings of the 51st Ruakura Farmers' Conference.

Pierre, J.J.; Jackobs, J.A. 1953. The effect of cutting treatments on birdsfoot trefoil. Agronomy Journal 45: 463-468.

Ramirez-Restrepo, C.A.; Kemp, P.; Barry, T.N.; LopezVillalobos, N. 2006. Production of Lotus corniculatus L. under grazing in a dryland farming environment. New Zealand Journal of Agricultural Research 49: 89-100.

Sheaffer, C.C.; Marten, G.C.; Ristau, E.A. 1992. Forage potential of kura clover and birdsfoot trefoil when grazed by sheep. Agronomy Journal 84: 176-180.

Singleton, P.L. 1991. Soils of Ruakura - a window on the Waikato. DSIR Land Resources Scientific Report.
No. 5. 122 p.

Waghorn, G.C.; Douglas, G.B.; Niezen, J.H.; McNabb, W.C.; Foote, A.G. 1998. Forages with condensed tannins - their management and nutritive value for ruminants. Proceedings of the New Zealand Grassland Association 60: 89-98.

Widdup, K.H.; Rumball, W.; Rolston, M.P.; Archie, B.J. 2004. Productivity of Lotus corniculatus and $L$. pedunculatus cultivars with and without tall fescue under sheep grazing. Proceedings of the New Zealand Grassland Association 66: 273-278.

Woodward, S.L.; Auldist, M.J.; Laboyrie, P.G.; Jansen, E.B.L. 1999: Effect of Lotus corniculatus and condensed tannins on milk yield and milk composition of dairy cows. Proceedings of the New Zealand Society of Animal Production 59: 152-155. 